Chapter 14

\title{
Provenance Trials in Alpine Range - Review and Perspectives for Applications in Climate Change
}

\author{
Stefan Kapeller, Silvio Schüler, Gerhard Huber, \\ Gregor Božič, Tom Wohlgemuth and \\ Raphael Klumpp
}

Additional information is available at the end of the chapter

http://dx.doi.org/10.5772/56283

\section{Introduction}

Effects of climate change on forest ecosystems and the mitigation of negative consequences to ecosystem functions and economic forest services are major challenges for current forest science and management [1-3]. Impact of climate change on forest ecosystems in Europe has been discussed controversially. It is generally agreed that increasing temperatures will lead to higher photosynthetic activity, faster growth and therefore higher forest net productivity, at least in large parts of central and northern Europe [4,5]. However, increasing incidences of drought events and poor water supply are assumed to be limiting factors for tree growth in the future [6,7], and the most productive coniferous species (e.g. Norway spruce) very likely cannot survive under future conditions in all parts of their natural range or cultivation area, respectively $[8,9]$. This will have severe implications for forest management and the wood processing industry. For example, the financial effects of climate change due to biome shifts from productive coniferous forest to Mediterranean oak forests would result in a decrease of the expected value of European forest land between 14 and 50\% [10].

Most tree species are distributed throughout large geographic ranges, where they experience a wide range of environmental conditions. The limits of these conditions are being considered to form the environmental niche of the species, for example see [11, 12]. However, the environmental variation within the species' ranges also creates manifold local adaptations to climate and site conditions. To identify and understand these local adaptations offers perspectives to maintain the existing tree species composition by using seed material that shows adaptation to future conditions. 
Variation in climatic conditions is especially high throughout the Alpine region. Due to the multitude of environmental conditions within small distances and within a fragmented mountain terrain, Alpine space harbors high biological diversity [13]. At the same time, mountain ecosystems seem to be particularly vulnerable [14] and climate change is likely to induce severe habitat loss habitat for a majority of alpine plant species [15] and to threaten biodiversity in Alpine space [16, 17].

In order to mitigate the climate change impact on forestry in Alpine space and to adapt forest management accordingly, it is necessary to understand how forest tree species respond to changing climates. Provenance tests provide valuable data for the investigation of climate adaptation of forest species and intraspecific variation in climate response among tree populations.

The present study aims to review the utilization of provenance tests for revealing the intraspecific variation in climate response of trees and the development of adaptation measures for climate change. First, a general overview of climate adaptation of trees, affected adaptive traits and evolutionary and demographic processes is given and the application in climate change mitigation is discussed. Secondly, we describe general methodological issues of provenance tests and statistical approaches to reveal climate responses. Thirdly, we compile information about established provenance tests in the Alpine range and analyze their potential utilization for adaptation studies. Finally, we discuss abundant problems with climate response analyses and derive recommendations for the conception of future provenance trials.

\section{Climate adaptation in trees}

Studies on phenotypic traits demonstrated that forest tree populations exhibit substantial local adaptation, for example see [18]. This is thought to be mainly a result of diversifying selection caused by environmental heterogeneity [19]. Phenotypic traits that evolved through local adaptation are often referred to as adaptive genetic variation (e.g. [20]). Adaptive traits have been observed on the juvenile and the adult phase for many tree species. In the past, adaptive traits have been correlated mainly to the geographical origin of the analysed provenances, i.e. latitude or altitude. Recently, the availability of high resolution climate parameters allowed a direct relation of phenotypic traits to the climate parameters shaping it. Table 1 gives a short overview about typical adaptive traits that were found in the most important tree species of the Alpine space.

The evolutionary basis of local adaptation is natural selection causing changes of the mean phenotypic values to fit the climate optima of the respective environment [18]. In trees, selection is considered to be mainly active during seedling establishment, because trees possess long generation times and produce huge quantities of offspring [41]. Thus, mortality is strongest in the juvenile phases. The molecular basis for phenotypic variation is nucleotide variation at few or many individual loci (e.g. $[42,43])$. The impact of selection on the traits underlying genes can be either through the fixation of single beneficial mutations [44] or on the basis of standing genetic variation on many genes where small changes of allele frequencies create substantial trait variation (e.g. [45]). Recent studies on quantitative trait loci and 
candidate genes suggest that for adaptive genetic variation the latter might be more common than previously thought [46]. Due to this complex trait architecture, selection on each gene is small, and thus high levels of standing genetic variation might be retained even in locally adapted populations [47].

Also, gene flow through steep environmental gradients may contribute substantially to genetic variation within populations and creates both, a genetic load and a higher adaptive potential in the subsequent populations [48]. However, even in cases of extensive gene flow, divergent selection acting on adaptive traits may result in a rapid increase of quantitative differentiation depending on the interpopulation allelic covariation of the underlying genes [49]. Further complexity might be added through epigenetic regulation of gene expression patterns [50, 51]. Overall, the contribution of nucleotide variation, allelic covariation, or gene expression patterns to phenotypic variation still needs to be deciphered.

\begin{tabular}{|c|c|c|}
\hline Trait & Species & Literature \\
\hline \multirow[t]{5}{*}{ Bud break (S) } & Picea abies & {$[21,22]$} \\
\hline & Abies alba & {$[23,24]$} \\
\hline & Larix decidua & {$[25]$} \\
\hline & Pinus sylvestris & {$[26]$} \\
\hline & Fagus sylvatica & {$[27]$} \\
\hline \multirow[t]{2}{*}{ Bud set (S) } & Picea abies & {$[28,29]$} \\
\hline & Pinus sylvestris & {$[30]$} \\
\hline \multirow[t]{3}{*}{ Seedling height (S) } & Picea abies & {$[28,31]$} \\
\hline & Pinus sylvestris & {$[30]$} \\
\hline & Abies alba & {$[23,24]$} \\
\hline Biomass (S) & Picea abies & {$[31]$} \\
\hline \multirow[t]{5}{*}{ Tree height / Diameter at breast height (T) } & Picea abies & {$[22,32]$} \\
\hline & Abies alba & {$[33]$} \\
\hline & Larix decidua & {$[25,34,35]$} \\
\hline & Pinus sylvestris & {$[36,37]$} \\
\hline & Fagus sylvatica & [38] \\
\hline \multirow[t]{2}{*}{ Frost resistance $(\mathrm{S} / \mathrm{T})$} & Picea abies & [39] \\
\hline & Pinus sylvestris & {$[30]$} \\
\hline \multirow[t]{2}{*}{ Drought resistance } & Larix decidua & {$[40]$} \\
\hline & Abies alba & {$[23,113]$} \\
\hline
\end{tabular}

Table 1. Overview of adaptive traits in alpine species, i.e. phenotypic traits of seedlings (S) or adult trees (T) that were found to be related to the environmental conditions of the seed provenance. 
Besides selection and local adaptation, also neutral population genetic processes (i.e. drift, population expansion, migration, gene flow) are likely to affect the distribution of adaptive genetic variation. Overall, the genetic structure of temperate tree species has been strongly affected by historical processes: in particular, range contractions and expansions during quaternary climatic oscillations (ice ages) have shaped the current pattern of diversity (e.g. [52]). Thus, the admixture of adaptive variation from different postglacial lineages has been found to play a significant role in the current environmental clines of adaptive traits [53]. The decrease of genetic diversity from southern refugial populations to northern ones can be explained by bottleneck effects during colonisation or very rare events of long distance dispersal, e.g. [54,55]. Although only few efforts have been made to test for geographical trends of quantitative genetic trait variation across species geographical range [56], recent comparisons of neutral vs. adaptive genetic variation show that quantitative differentiation due to adaptation is strong also at northern range margins, thus highlighting the role of local adaptation and adaptive plasticity $[57,58]$.

\section{Application in climate change mitigation}

The impact of adaptive traits on forest management, conservation biology and genetics, and on climate adaptation is tremendous: for example, in forest management adaptive traits are the basis for the delineation of breeding zones and provenance regions, for example see [59, 60]. In conservation biology adaptive traits are increasingly recognized as an ecologically important quality, thus need to be considered in restoration projects [61, 62]. For the genetic management of endangered populations, adaptive traits play a key role in developing translocation and genetic rescue schemes [63-65]. The high differentiation of adaptive traits and their strong correlation to environmental variables give them a paramount importance for developing adaptive forest management strategies to cope with climate change. Generally, two strategies can be used to test for local adaptation and to develop seed transfer schemes: First, seedling studies, where large numbers of seed provenances from different geographic origin (and therefore often also from different climatic origin) are planted under controlled conditions in a nursery of climate chambers, e.g. [28]. Seedling studies often reveal high correlations of phenotypic and phenological traits with environmental variables [66]. This correlation can be used as predictors for adaptation or maladaptation to current and future environmental conditions [67]. Secondly, provenance tests, where seed material from different origin is planted at several different test sites and being measured for at least 10-30 years, e.g. [68].

Seedling studies can be realised within few years. However, they are based only on one or very few test environments, and therefore their validity for predicting the long-term stability of provenances under a wide range of conditions is limited. On the other hand, seedling studies allow direct tests for extreme conditions, e.g. simulated drought or frost [69] and may therefore mimic effects that under natural conditions only take place on rare occasions. To observe the effect of such single extreme events in provenance tests is difficult, because they are usually controlled and measured in periods of one to five years. Therefore, they can only provide a 
surrogate for the general fitness of the tested genetic material under the given conditions. Fitness in provenance trials is measured mainly as survival, height or d.b.h., but with additional dendroclimatic measures also the intraspecific variation of climate-growth relationship can be assessed $[70,71]$.

True comparisons of seedling studies with subsequent provenance tests using the same genetic material are rare, but recent investigation with material from the same distribution area suggests, that seedling studies overestimate local adaptation and provenance test series show a more uniformly distributed genetic variation (for example, see [66, 72]).

\section{Provenance trials history and test design}

The creation and utilization of provenance tests for the analysis of intraspecific variation of trees goes back to the 18th century. Early common garden experiments were often established in a consistent test design and aimed at identifying well growing and suitable seed sources for reforestation. Langlet [73] credits the comparative cultures of pine established by H.L. Duhamel du Monceau between 1745 and 1755 as the first milestone of such genecological studies [74]. Although the experiments by Duhamel du Monceau rather aimed at gaining sufficient material for shipbuilding than scientific insights in intraspecific variation of pines [74], they attest an early awareness of local adaptations and the relationship between adaptive tree traits and different environmental conditions at the seed source origins.

Analyzing local adaptations and utilizing this information to find appropriate seed material has been a primary objective of provenance tests for more than 200 years [73, 75]. Later, provenance tests have also been used for seed transfer and utilization schemes and more recently, to develop adaptation measures for climate change, for examples, see [67, 68, 76-79]. Due to the wide range of objectives various test designs have been developed, all termed provenance tests or progeny trials. Morgenstern [75] classified all experimental setups with tree provenances according to the test environment in 1) growth cabinet and greenhouse experiments, 2) nursery experiments and 3) field experiments. While growth cabinets and nursery experiments are usually used for short term investigations, field experiments are established for periods of many years with iterated measurements. Actually, the very old provenance tests (tree age $>30$ years) do often yield the most valuable results, since they enable reliable statements about the potential productivity of a specific stand.

The basic test design for provenance trials is a common garden test, where seedlings from different provenances are grown parallel under site conditions as similar as possible. However, the actual soil or environmental conditions for each plant are varying even within a mostly homogeneous test area (but see [80] on how to remove such effects). Therefore, trees are planted in multiple repetitions to compensate for any site heterogeneities. The most common layout plan is a randomized block design, which can be either complete, i.e. all provenances are planted throughout all blocks (repetitions) or incomplete, where the blocks do not contain the complete set of provenances. Moreover, in field trials over several sites, it can be distinguished between balanced and unbalanced designs, wherein the latter, the same provenances 
are not tested at all sites. For such unbalanced trials it has been recommended to use certain provenances as standard populations to which the others can be compared [74]. More details and guidelines for setting up field trials can be found in [74, 81, 82].

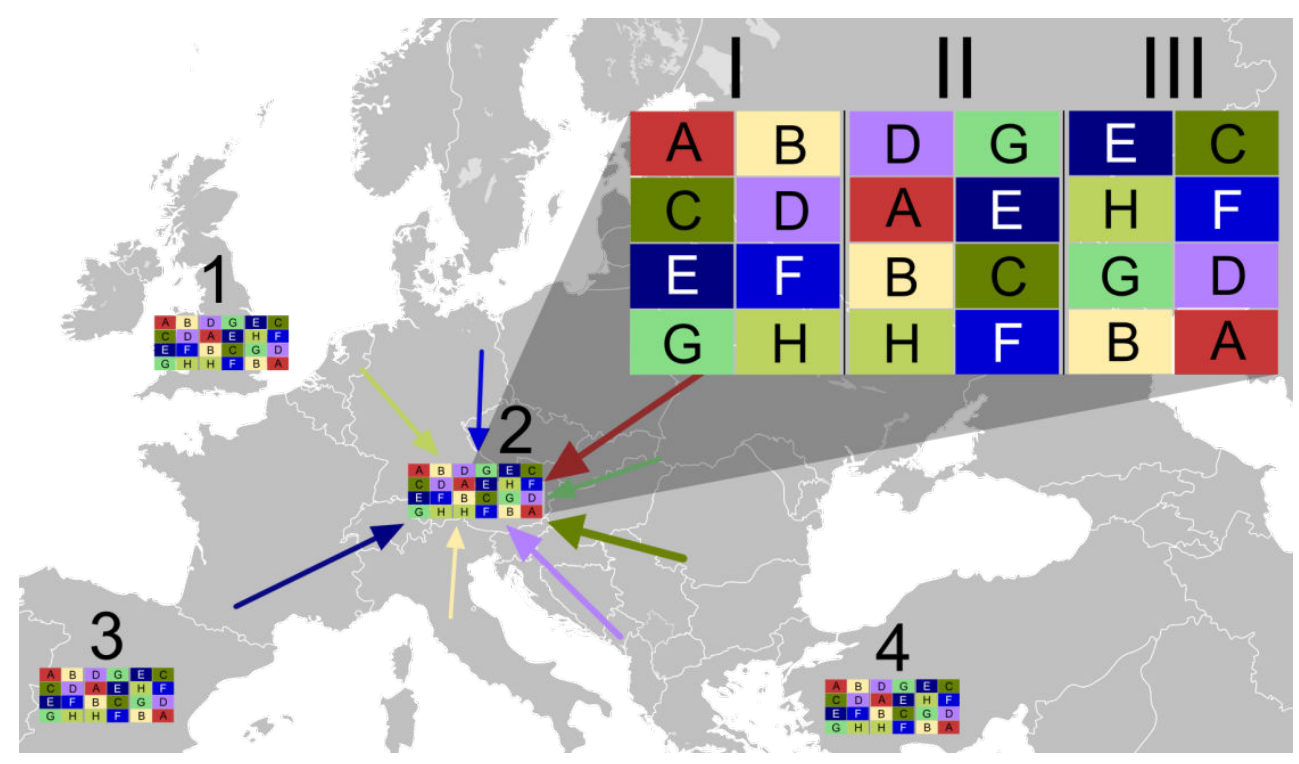

Figure 1. General scheme provenance test series. An exemplary trial series with 4 test sites (1-4) using a complete randomized block design is shown. Each provenance $(\mathrm{A}-\mathrm{H})$ is planted in (typically) three repetitions (block I-III) at each site. Each single plot (colored rectangles) consists of multiple individuals of the same provenance.

A scheme of the most common test design, the randomized complete block layout (RCB), is shown in figure 1 . This test design has proved to be useful for many issues and environments and the basic setup did not changed during past decades. However, methods of data analyses did improve significantly. Powerful statistical tools are available due to increasing computer resources. Due to a growing amount of data derived from trials established in the past decades, it is very often worth utilizing this old data for further analyses employing modern statistical tools.

\section{Climate response analyses with provenance test data}

Ecological niches of species and populations are a fundamental concept in ecology. Usually the term refers to the 'Hutchinsonian multidimensional hypervolume', which is defined as the set of biotic and abiotic conditions in which a species is able to persist and maintain stable population sizes [83]. The 'fundamental niche' represents that portion of the environmental gradient within which existence is possible. By biotic interactions individuals of a species are 
excluded from a part of their fundamental niche, resulting in the realized niche that is observed in nature [84].

As a result of adaptation processes to a population's habitat, the fitness of the population has an optimum somewhere within the fundamental niche which decreases towards the edge areas. This linkage between fitness or fitness proxy parameters and climate variables has been studied for different tree species, e.g. Pinus banksiana [68], Pinus sylvestris [37], Pinus contorta [77], Picea abies [39]. To analyze the correlation between population specific quantitative traits and climate conditions several approaches have been developed. In its basic most common form, a climate response function is a univariate regression analysis with a single response variable (quantitative trait) and a single (climatic) predictor variable. Modelling approaches vary in regard to the chosen response and predictor variables and the applied mathematical model. In order to follow the ecological niche model, quadratic, Gaussian or Weibull models are preferred. If climate conditions of provenance origins and planting sites are both known it is possible to derive climate response functions and/or climate transfer functions.

Climate response functions depict the correlation between a quantitative trait of a specific tree population and distinct climate conditions at its planting sites. The respective genotype of a tree population translates to different phenotypes when exposed to variable growing environments (Fig. 2). The resulting pattern of the conditional trait response is also termed reaction norm. The specific objective of studies using climate response functions is to determine those climatic conditions, where the trait of interest is expressed in its most favorable shape. Such conditions may be defined as the climate optimum.

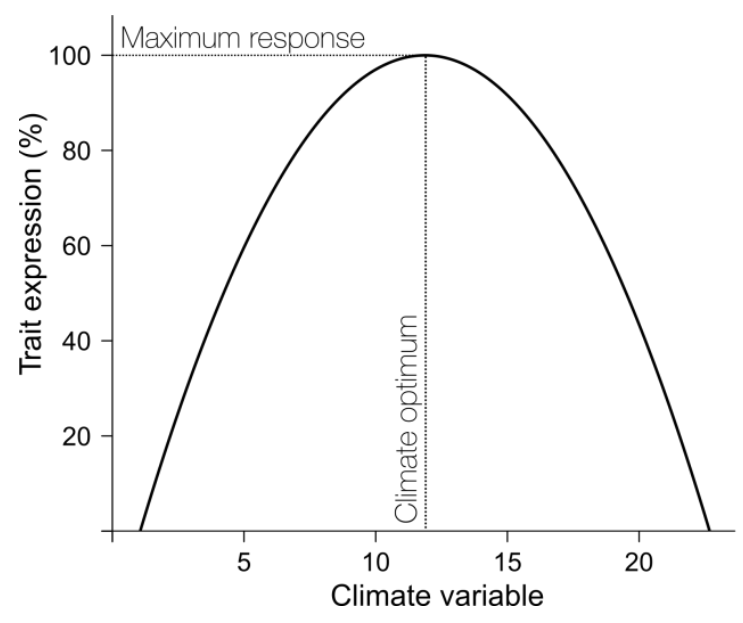

Figure 2. Schematized (quadratic) climate response function. Maximum response of the measured trait at a specific climate optimum is indicated.

Climate transfer functions include information about the climate of the provenance origins. Here, the quantitative traits are usually correlated to the climate transfer distance, i.e. the 
climatic difference between planting site and provenance origin. It is generally hypothesized that tree populations are best adapted to their local climate conditions. Therefore, the best growth performance is expected at small climate transfer distances, whereas at larger climatic distances, trees are maladapted and are thought to perform worse. Climate transfer functions can be derived for individual sites if data from sufficient populations from diverse climatic origins are available (Fig. 3). If the study comprises more than one planting site, data cannot directly be compared among sites with absolute units of measurements. Instead, relative performances to site means should be calculated. Thereby, site specific growth limitations (altitude, soil, climate) are eliminated and across site comparisons are possible.

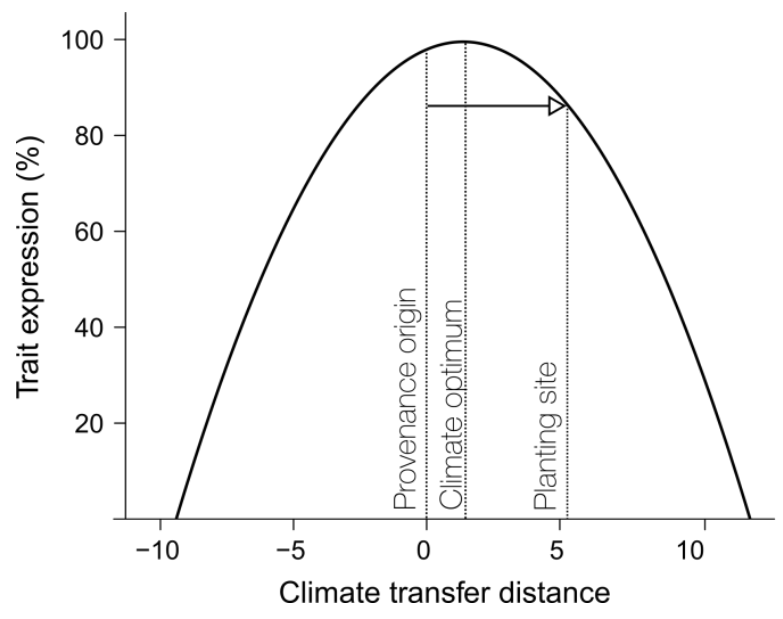

Figure 3. Schematized (quadratic) climate transfer function. The arrow indicates the transfer from the provenance origin to the planting site.

Both climate function types response functions and transfer functions can be utilized for combined analyses in universal response functions [85, 86, 88]. Universal response functions employ each site's transfer function to enhance response functions of all populations. In this way, all available information from any provenance at any test site is utilized to estimate a joined "universal" response of population to a given environmental factors. Such approach might compensate for unbalanced experimental setups with multiple test sites. Still, for statistical significant estimations, a large number of provenances and test sites are necessary. For example, reference [86] used results from a provenance test with lodgepole pine, comprising 140 populations at 62 sites, to calibrate a universal response function (Fig. 4). Test series spanning such a large climate range are rarely available.

However, incorporating information from both environmental effects of test site climate on phenotypes (accounted for by response functions) and among-population differentiation resulting from local adaptation to climate (accounted for by transfer functions) into a single "universal response function" reduces the necessary number of tested populations and test sites, while keeping the same predictive power [86]. Therefore, this integrative approach is 
promising for analyses of incomplete test designs that would be insufficient for establishing transfer or response functions [86]. Furthermore, combined with a sophisticated sampling strategy and choice of test sites, future provenance tests could be designed much more effectively. For example, both population and test site sample size could be by $65 \%$ without affecting the prediction accuracy of the universal response function [86].

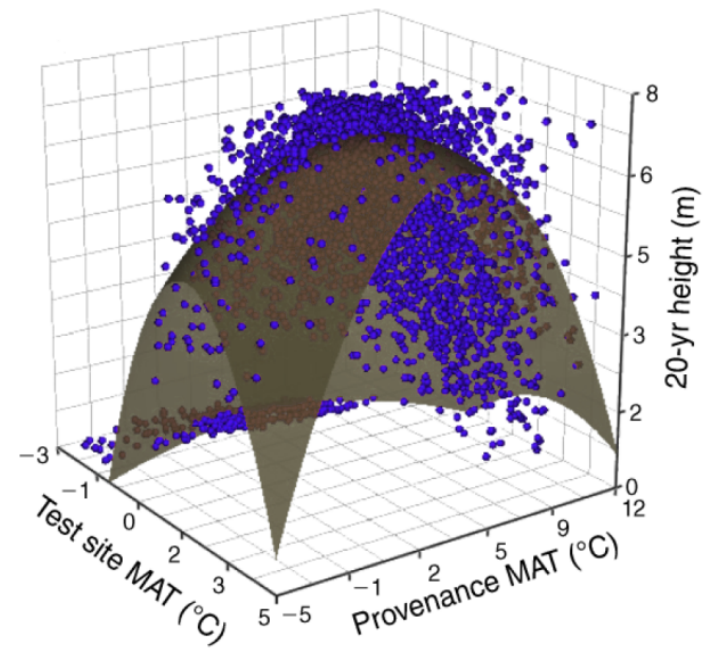

Figure 4. Universal response function including mean annual temperature (MAT) at test site and provenance origin (modified from Wang et al. [86]).

The mathematical model, which is fit to the obtained data, must be chosen carefully. Among the most commonly applied model functions are quadratic [37], Gaussian [87], Weibull [89] or Beta function [90]. In many cases more than one model would be appropriate from a statistical point of view. Several statistical tests and criteria may help in finding the most suitable model (goodness of fit). However, it is difficult to find the most appropriate approach, especially if only few data points are available or if upper and lower limits of the climatic niche are spurious.

Other problems arise for joint evaluations of provenance test series with multiple test sites, especially with incomplete designs, where different provenances have been tested at each site. This issue is addressed in reference [86] by utilizing universal response functions (see above). The classic approach to overcome this issue is the planting of a set of standard provenances at every site allowing for unbiased comparisons among sites. Though, the standard's value relative to other provenances need not be the same on all sites due to provenance $\mathrm{x}$ site interactions [32]. A method for joint analyses has been proposed in [32, 91], suggesting to present the results in standard deviations of the respective experimental mean at a given age [74]. However, this cannot effectively compensate inconsistent forest management activities or inconsistent data measuring practices. If such inhomogeneities and biases affect the validity 
of statistical analyses must be clarified case-to-case and should be well documented at any rate.

Aside from choosing an appropriate model function, the finding of the relevant climate parameter and predictor variables that drive selection is difficult. As local performance and productivity of tree populations are adapted to specific climate or environmental conditions, the selection forces driving this adaptation may vary from site to site. For example, whereas in warm regions tree productivity might possibly be limited by the extent of drought periods, in mountainous areas the limiting factor might rather be frost resistance and cold hardiness [92]. Especially in Alpine regions, where heterogeneous climates occur within small geographic ranges, a bunch of selection forces may play a role: for example, growth performance of Norway spruce was found to be positively related to temperatures in May and June at higher altitudes, and negatively related to temperatures of the same months at lower elevation [93]. In higher altitudes frost tolerance and stability is of paramount importance, in lower altitudes best exploitation of vegetation season has higher priority [92, 94]. However, most climate response functions concern only one or few climate parameters and do not reflect multiple effects, which may shape the actual population niche.

\section{Minimum requirements for calculating response functions from provenance test data}

Provenance experiments have been established with many different objectives, climate analyses being only one among them. Older trials were probably not established for the development of climate response functions or climate change adaptation measures. Such trials may be of limited or no use for the further analyses.

To use data of provenance experiments for the development of adaptation schemes, the field data have to fulfill few requirements: First, seed collections and the seed origins have to be well documented. Coordinates of provenances and test sites should be available as accurate as possible. Also, seed origins should be mostly autochthonous in order to find adaptations to the local climate. Second, provenances should be planted on a wide spectrum of test sites covering at least the natural range of climate conditions where the species occurs. If possible, few test sites should be beyond the natural range of the respective species. Third, for climate transfer and universal transfer functions it is also necessary to collect provenances from a wide climatic range in order to enable statistically valuable calibrations. Many provenance experiments do not meet all of these requirements sufficiently, which might result in low statistical power.

\section{Provenance trials in Alpine space - Overview}

From the oldest provenance trial with Norway spruce, established by Kienitz in 1881 (sowing 1878) at Gahrenberg, only descriptive observations are available [95]. In the Alpine space the altitude of population origins has early been recognized as a particular important factor. For 


\begin{tabular}{lcc}
\hline Requirement & CRF & CTF \\
\hline Coordinates from provenance origins and test sites & $X$ & $X$ \\
\hline Seed source material from presumably autochthonous stand & $X$ & $X$ \\
\hline Seed collection involved multiple mother trees per population & $X$ & $X$ \\
\hline Uniform forest management measures at test sites & $X$ & $X$ \\
\hline Populations have been tested at sufficient test sites & $X$ \\
\hline Wide climatic range of tested populations & $X$ \\
\hline Wide climatic range of test sites & $X$ \\
\hline Sufficient climatic range of sites, where each populations has been tested & $X$ & $X$ \\
\hline Measurement data of the field trials should be available in the raw form & \\
\hline
\end{tabular}

Table 2. Minimum requirements for climatic analyses of provenance test data. Right columns indicate if the respective criterion should be fulfilled to calibrate climate response functions (CRF) or climate transfer functions (CTF).

example, in Austria, Cieslar compared tree growth among Norway spruce offspring from different altitudinal ranges at three planting sites $[96,97]$ in 1899 . Trees have been evaluated several times afterwards $[96,98]$. Latest results at the tree age 58 indicate an assimilation and reduction of growth-differences among populations. Engler (see [99]) established a similar experiment in 1899 with five Suisse provenances of Norway spruce. The provenances were planted at 16 sites in altitudes from $380 \mathrm{~m}$ to $2150 \mathrm{~m}$ [99]. In both experiments, considerable differences in survival, growth and tree shape among provenances were found.

Table 3 gives an overview of provenance tests of Norway spruce that have been established in the Alpine space. Within the project MANFRED, they were reviewed and rated according to their potential application in climate adaptation studies. From the many trials that were established in the past 100 years, most trials did not fit. In some cases provenances were tested only under "colder" climate conditions, but not in warmer environments. Also, due to the long observation times, many trial data only exist in form of published tables or figures but not within their raw form. Provenance tests which might be used for climate adaptation analyses are listed in table 3 for Picea abies and table 4 for Abies alba.

The three IUFRO trial series (1938, 1964/68 and 1972) are especially interesting for potential climate related analyses, since both the test sites and the utilized provenances cover a wide climatic range. However, data are not fully available and despite many efforts, data exchange among involved institutions was not successful until now. Nevertheless, the national provenance tests mentioned in table 3 and 4 are also valuable sources for analyses and should be reanalyzed in relation to climate data. As an example we present some results from the Austrian provenance test of 1978 in chapter 4.

The IUFRO silver fir test series have been initiated by H. Mayer, who was impressed by reports on Silver fir dieback during the early sixties of the $20^{\text {th }}$ century [112]. Aiming in a holistic 


\begin{tabular}{|c|c|c|c|c|c|c|c|c|}
\hline $\begin{array}{l}\text { Name } \\
\text { (initiator) }\end{array}$ & $\begin{array}{l}\text { Country } \\
\text { (coord.) }\end{array}$ & $\begin{array}{l}\text { Year sown } \\
\text { (plant.) }\end{array}$ & Sites & Prov.range & Design & Lit. & RF & TF \\
\hline Cieslar & AT & $\begin{array}{l}1893 \\
(1896)\end{array}$ & $1(\mathrm{AT})$ & Alp. space & 1 rep; ST harvest & & - & $(X)$ \\
\hline Cieslar & AT & 1899 & 3 & Mostly AT $(80+1)$ & 1 rep; ST harvest & {$[96,98]$} & - & $(X)$ \\
\hline Engler & $\mathrm{CH}$ & 1899 & 16 & $\mathrm{CH}(5)$ & MT harvest & [99] & $x$ & $(X)$ \\
\hline Holzer & AT & 1978 & 44 & $\begin{array}{l}\text { AT }(480)+\text { Alp. } \\
\text { space }(60)\end{array}$ & $\begin{array}{l}\text { RCBD; } 3 \text { rep; MT } \\
\text { harvest }\end{array}$ & {$[100]$} & $x$ & $x$ \\
\hline Bouvarel & FR & 1957 & $1(\mathrm{FR})$ & $\mathrm{FR}(14)+\mathrm{AT}(1)$ & & [101] & & \\
\hline Fröhlich & DE & 1962 & $5(\mathrm{DE})$ & Nat. range (530) & Lattice square & [102] & $(X)$ & $x$ \\
\hline Pavle & SI & $\begin{array}{l}1984 \\
(1987)\end{array}$ & 1 & SI (10) & 3 rep & & & $x$ \\
\hline $\begin{array}{l}\text { IUFRO } 1938 \\
(+39)\end{array}$ & $\begin{array}{l}14 \text { countries } \\
\text { (Schmidt, DE) }\end{array}$ & $\begin{array}{l}1938 \\
(1940-1944 \\
)\end{array}$ & $\begin{array}{l}25(+2) \\
\text { (in) }\end{array}$ & Nat. range (36) & MT harvest & [32] & $x$ & $x$ \\
\hline IUFRO 64/68 & $\begin{array}{l}13 \text { countries } \\
\text { (Langlet, SE) }\end{array}$ & $\begin{array}{l}1964 \\
(1968)\end{array}$ & 21 & Nat. range (1100) & RCBD; MT harvest & $\begin{array}{l}{[102,} \\
103]\end{array}$ & $x$ & $x$ \\
\hline IUFRO 1972 & $\begin{array}{l}11 \text { countries } \\
\text { ( Tyskiewicz / } \\
\text { Matras) }\end{array}$ & 1972 & 44 & $\mathrm{PL}(20)$ & MT harvest & & $x$ & $x$ \\
\hline
\end{tabular}

Table 3. Overview of Norway spruce trials in Alpine space. Information about the respective test series is given if available, including year of establishment, No. of involved sites, range of tested provenances, test design (RCBD = Randomized complete block design, rep = no. of repetitions, harvest of single (ST) or multiple (MT) trees). The potential of data for utilization in climate response functions (RF) and/or climate transfer functions (TF) is given. Brackets indicating limited use due to deficits in study design or data availability.

research design for testing genetic variation in general as well as drought resistance, he established a trial using 19 international provenances under summer warm climate conditions of the rim of the Viennese forest in Austria in 1970 [33]. The Austrian silver fir trial served as pilot study for the " 1 st International Silver fir provenance trial 1982" which was organized by Kramer [107]. Seeds from eleven provenances from central and southern Europe were sent to forestry institutes in Germany, Netherlands, Austria, Suisse, Slovenia, Poland and Slovakia to establish in total 27 trials [108]. Six of eleven provenances were tested at every test site as standards. In spite of detailed plans for a joint evaluation of all tests and a central database in Vienna [107], the data were recorded individually and published separately without any coordination. A further comprehensive test series was established in South Germany in 1982 using 42 south German and 17 provenances originating from the whole European Silver fir range, including the provenances of the $1^{\text {st }} I U F R O$ trial [109]. Finally, the $2^{\text {nd }}$ International Silver fir provenance test was established in 2005, in order to get better information on the variation of SE-European provenances [111]. 


\begin{tabular}{|c|c|c|c|c|c|c|c|c|}
\hline Name (initiator) & $\begin{array}{l}\text { Country } \\
\text { (coord.) }\end{array}$ & $\begin{array}{l}\text { Year sown } \\
\text { (plant.) }\end{array}$ & Sites & Prov. range & Design & Lit. & RF & TF \\
\hline $\begin{array}{l}\text { Czecho-slovakian } \\
\text { prov. test with } \\
\text { Silver fir }\end{array}$ & SK & $\begin{array}{l}1965 \\
(1970)\end{array}$ & 2 (SK) & 27 & RCBD , 3 rep. & {$[104]$} & & $x$ \\
\hline $\begin{array}{l}\text { Int. Silver fir prov. } \\
\text { trial (IUFRO pilot } \\
\text { study 1967) }\end{array}$ & $\begin{array}{l}\text { H. Mayer } \\
\text { (AT) }\end{array}$ & $\begin{array}{l}1967 \\
(1970)\end{array}$ & $1(\mathrm{AT})$ & 19 & RBD, 2 rep. & {$[33,105]$} & & $x$ \\
\hline $\begin{array}{l}\text { South German } \\
\text { Silver fir prov. } \\
\text { trial }\end{array}$ & $\mathrm{DE}$ & $\begin{array}{l}\text { 1982/83 } \\
(1986-1989 \\
)\end{array}$ & 19 (GE) & $\begin{array}{l}\text { DE (42) + Intern. } \\
(17)\end{array}$ & 3 rep. & {$[106]$} & $x$ & $x$ \\
\hline $\begin{array}{l}1^{\text {st }} \text { Int. IUFRO } \\
\text { Silver fir prov. } \\
\text { test } 1982\end{array}$ & $\begin{array}{l}\text { Kramer } \\
(\mathrm{DE})\end{array}$ & $\begin{array}{l}1982 \\
(1986)\end{array}$ & 27 & $\begin{array}{l}\text { Centr.+South. } \\
\text { Europe (11) }\end{array}$ & RBD & {$[107,108]$} & $x$ & $x$ \\
\hline $\begin{array}{l}2^{\text {nd }} \text { Int. IUFRO } \\
\text { Silver fir prov. } \\
\text { test } 2005\end{array}$ & $\begin{array}{l}\text { Eder (DE), } \\
\text { Klumpp } \\
\text { (AT) }\end{array}$ & $\begin{array}{l}2000 \\
(2005)\end{array}$ & 5 & $\begin{array}{l}\text { Centr.+SE. } \\
\text { Europe (17) }\end{array}$ & RCBD, 3 rep. & [111] & $x$ & $x$ \\
\hline
\end{tabular}

Table 4. Overview of Abies alba trials in Alpine space. Information about the respective test series is given if available, including year of establishment, No. of involved sites, range of testes provenances, test design (RCBD = Randomized complete block design, rep = no. of repetitions, harvest of single (ST) or multiple (MT) trees). The potential of data for utilization in climate response functions (RF) and/or climate transfer functions (TF) is given. Brackets indicating limited use due to deficits in study design or data availability.

Apart from the international series there have been several national provenance tests established. Earlier national experiments using seed provenances from the Alpine space had been started for example in Italy [110] and Slovakia 1965 [104].

\section{Case study - Austrian provenance test with Norway spruce 1978}

A comprehensive provenance test with Norway spruce has been established in 1978 at 44 sites across Austria. The trial included seeds from 480 Austrian provenances and 60 provenances from other countries [100]. At tree age 15, height has been recorded at 29 of these 44 trial sites. These data have been used in the present project to analyze the intraspecific variation in climate response [87]. In order to reveal more general insights, provenances with similar climatic conditions were aggregated in provenance clusters. The response of the nine resulting clusters to a heat-moisture index was calculated using a Gaussian distribution model.

The results hardly revealed any declines in potential tree growth of Norway spruce throughout its current distribution range in Austria. In fact, for most parts of Austria we found an expected increase of tree heights up to 45 percent until 2080. In general, provenances from currently warm and drought prone areas seem to be well adapted to respective climate conditions and 
may be appropriate candidates for extended utilization in future. However, the impact of a warming climate is different for individual provenance groups (Fig. 5). Thus, an optimized choice of seed material according to prospective future climate conditions has the potential for an additional increase of productivity up to 11 percent [87]. Although this study sets focus on provenances of the eastern Alps and the Bohemian Massif in Austria, some results of this most extensive provenance trial in the Alpine space can be generalized beyond the Austrian border, because firstly, although the provenances origin from a relatively small part of the natural range of Norway spruce, they cover the three main refugial lineages which build the basis of all natural Norway spruce populations in Central and Western Europe, and secondly, the provenance trial series has been established along a wide gradient of climate conditions ranging from $2.6^{\circ} \mathrm{C}$ to $9.2^{\circ} \mathrm{C}$ mean annual temperature and annual precipitation values from $535 \mathrm{~mm}$ to $2392 \mathrm{~mm}$. Thus, it covers not only a large part of current Norway spruce habitats, but also extends into sites at the warm and dry edge of its distribution, making it highly suitable to analyze the potential response to a changing climate.

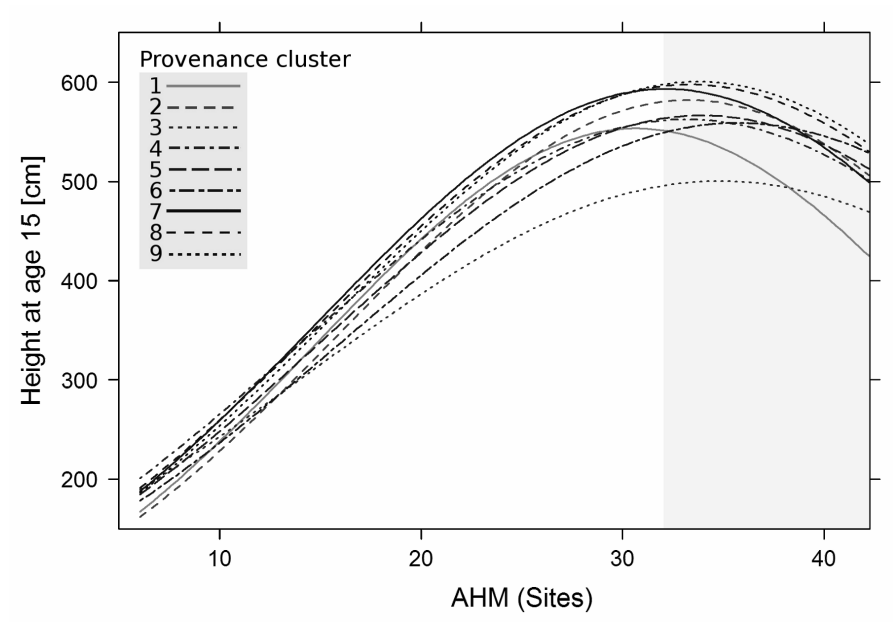

Figure 5. Response functions of nine provenance clusters of the Austrian Norway spruce provenance trial 1978. Gaussian functions of tree heights at age 15 fitted to heat-moisture index AHM (mean annual temperature + 10 / (Annual precipitation sum / 1000)) of planting sites [77]. Response functions are given for nine groups of provenances which originate from similar climates. Grey area denotes AHM-regions beyond current maximum $\left(32^{\circ} \mathrm{C} / \mathrm{mm}\right)$ to future maximum $\left(42.3^{\circ} \mathrm{C} / \mathrm{mm}\right)$ limits.

\section{Conclusion}

Many provenance tests have been established for tree species in the Alpine space within the last 200 years. These trials are based on a laborious work from its initial establishment to the often comprehensive and numerous measurements. Today, such data are strongly needed for a better understanding of the intraspecific variation of climate response of tree species and for 
the development of provenance transfer and deployment schemes in the light of climate change. Within the last 20 years, the theoretical and statistical basis for the analysis of provenance climate responses was strongly improved. Also, high-quality climate data are freely available now. Therefore, new statistical analyses including all available data could substantially improve our understanding of climate growth relationships and evolutionary processes that cause intraspecific variation in climate adaptation. However, raw data from historic provenance test are only partly electronically available, and if they are, then access is usually limited to staff of responsible national institutions. Hence, efforts have to be made to make data easy accessible. Moreover, since meaningful climate response analyses require a considerable climate range of tests sites and tested population, transnational exchange of data and joined analyses are strongly needed, in order to cover the natural range of the respective species.

Furthermore, test design of previous provenance trials was optimized to find most appropriate seed sources for specific test sites and not to investigate general climate growth relations. As a consequence, only few test sites are established at the edges of the natural climatic range of tree species. Those climatically extreme sites are most valuable to detect upper and lower limits of tree species and tree populations and to calibrate well-founded response functions. Therefore, for future provenance tests we recommend to include test sites at the edges of the natural range of the respective tree species or even beyond.

\section{Author details}

Stefan Kapeller ${ }^{1}$, Silvio Schüler ${ }^{1}$, Gerhard Huber ${ }^{2}$, Gregor Božič ${ }^{3}$, Tom Wohlgemuth ${ }^{4}$ and Raphael Klumpp ${ }^{5}$

1 Federal Research and Training Centre for Forests, Natural Hazards and Landscape, Vienna, Austria

2 Bavarian Office for Forest Seeding and Planting, Teisendorf, Germany

3 Slovenian Forestry Institute, Ljubljana, Slovenia

4 Swiss Federal Institute for Forest, Snow and Landscape Research WSL, Birmensdorf, Switzerland

5 University of Natural Resources and Life Sciences, Vienna, Austria

\section{References}

[1] Prentice IC, Sykes MT, Cramer W. A simulation model for the transient effects of climate change on forest landscapes. Ecological Modelling 1993;65 51-70. 
[2] Lindner M. Forest management strategies in the context of potential climate change. Forstwissenschaftliches Centralblatt 1999;118 1-13.

[3] Maracchi G, Sirotenko O, Bindi M. Impacts of present and future climate variability on agriculture and forestry in the temperate regions: Europe. Climatic Change 2005;70 117-135.

[4] Peltola H, Kilpeläinen A, Kellomäki S. Diameter growth of Scots pine (Pinus sylvestris) trees grown at elevated temperature and carbon dioxide concentration under boreal conditions. Tree Physiology 2002;22 963-972.

[5] Matala J, Ojansuu R, Peltola H, Raitio H, Kellomaki S. Modelling the response of tree growth to temperature and $\mathrm{CO} 2$ elevation as related to the fertility and current temperature sum of a site. Ecological Modelling 2006;199 39-52.

[6] Modrzynski J. Response of Picea abies populations from elevational transects in the Polish Sudety and Carpathian mountains to simulated drought stress. Forest Ecology and Management 2002;165 105-116.

[7] Bréda N, Huc R, Granier A, Dreyer E. Temperate forest trees and stands under severe drought: a review of ecophysiological responses, adaptation processes and longterm consequences. Annals of Forest Science 2006;3 625-644.

[8] Davis MB, Shaw RG. Range shifts and adaptive responses to Quaternary climate change. Science 2001;292 673-679.

[9] Pearman PB, D'Amen M, Graham CH, Thuiller W, Zimmermann NE. Within-taxon niche structure: niche conservatism, divergence and predicted effects of climate change. Ecography 2010;33 990-1003.

[10] Hanewinkel M, Cullmann DA, Schelhaas MJ, Nabuurs G-J, Zimmermann NE. Climate change may cause severe loss in the economic value of European forest land. Nature Climate Change 2012;3 203-207.

[11] Sykes MT, Prentice C, Cramer W. A Bioclimatic model for the potential distributions of North European tree species under present and future climates. Journal of Biogeography 1996;23 203-233.

[12] Thuiller W, Lavorel S, Sykes MT, Araújo MB. Using niche-based modelling to assess the impact of climate change on tree functional diversity in Europe. Diversity and Distributions 2006;12 49-60.

[13] Spehn EM, Koerner C. A global assessment of mountain biodiversity and its function. In: Huber UM. et al. (eds.) Global change and mountain regions: an overview of current knowledge. Springer; 2005. p393-400.

[14] Theurillat J, Guisan A. Potential impact of climate change on vegetation in the European Alps: a review. Climate Change 2001;50 77-109. 
[15] Engler R, Randin CF, Thuiller W, Dullinger S, Zimmermann NE, Araújo MB, et al. 21st century climate change threatens mountain flora unequally across Europe. Global Change Biology 2011;17(7) 2330-2341.

[16] Thuiller W, Lavorel, S, Araújo MB, Sykes MT, Prentice IC. Climate change threats to plant diversity in Europe. Proceedings of the National Academy of Sciences of the United States of America 2005;102 8245-8250.

[17] Dirnböck T, Essl F, Rabitsch W. Disproportional risk for habitat loss of high-altitude endemic species under climate change. Global Change Biology 2011;17 990-996.

[18] Savolainen O, Pyhäjärvi T, Knürr T. Gene Flow and Local Adaptation in Trees. Annual Review of Ecology, Evolution, and Systematics 2007;38 595-619.

[19] Kremer A, Le Corre V, Petit RJ, Ducousso A. Historical and contemporary dynamics of adaptive differentiation in European oaks. In: DeWoody A, Bickham J, Michler C, Nichols K, Rhodes G, Woeste K (eds.) Molecular approaches in natural resource conservation. Cambridge University Press; 2010. p101-117.

[20] Holderegger R, Kamm U, Gugerli F. Adaptive vs. neutral genetic diversity: implications for landscape genetics. Landscape Ecology 2006;21 797-807.

[21] Lechner F, Holzer K, Tranquillini W. Über Austrieb und Zuwachs von Fichtenklonen in verschiedener Seehöhe. Silvae Genetica 1977;26 33-41.

[22] Hannerz M, Sonesson J, Ekberg I. Genetic correlations between growth and growth rhythm observed in a short-term test and performance in long-term field trials of Norway spruce. Canadian Journal of Forest Research 1999;29 768-778.

[23] Sagnard F, Barberot C, Fady B. Structure of Genetic diversity in Abies alba Mill.from southwestern Alps: multivariate analysis of adaptive and non-adaptive traits for conservation in France. Forest Ecology and Management 2002;157 175-189.

[24] Hansen JK, Larsen JB. European silver fir (Abies alba Mill.) provenances from Calabria, southern Italy: 15-year results from Danish provenance field trials. European Journal of Forest Research 2004;123 127-138.

[25] Schober R. Phänologie und Höhenwachstum der Lärche im Jahresverlauf in ihrer Abhängigkeit von Provenienz und Witterung. Beitrag zur Internationalen Ertragskundetagung 1966;433-483.

[26] Beuker E. Adaptation to climate changes of the timing of bud burst in populations of Pinus sylvestris L. and Picea abies (L.) Karst. Tree Physiology 1994;14 961-970.

[27] Wühlisch Gv, Krusche D, Muhs HJ. Variation in temperature sum requirement for flushing of beech provenances. Silvae Genetica 1995;44 343-346.

[28] Holzer K. Zur Identifizierung von Fichtenherkünften (Picea abies (L.) Karst.) Silvae Genetica 1975;24 169-175. 
[29] Holzer K. Die Kulturkammertestung zur Erkennung des Erbwertes bei Fichte [Picea abies (L.) Karsten]. 2. Merkmale des Vegetationsablaufes. Centralblatt für das gesamte Forstwesen 1978;95 30-51.

[30] Hurme P, Repo T, Savolainen O, Pääkkönen T. Climatic adaptation of bud set and frost hardiness in Scots pine (Pinus sylvestris). Canadian Journal of Forest Research 1997;27 716-723.

[31] Holzer K. Die Kulturkammertestung zur Erkennung des Erbwertes bei Fichte [Picea abies (L.) Karsten]. 3. Quantitative Merkmale. Centralblatt für das gesamte Forstwesen 1979;96 129-144.

[32] Giertych M. Summary results of the IUFRO 1938 Norway spruce (Picea abies (L.) Karst.) provenance experiment. Height growth. Silvae Genetica 1976;25 154-164.

[33] Mayer H, Reimoser F, Kral F. Ergebnisse des internationalen Tannenherkunftsversuches Wien 1967-1978, Morphologie und Wuchsverhalten der Provenienzen. In: Mayer H (ed.) 3. Tannen-Symposium. Vienna: Österreichischer Agrarverlag; 1980.

[34] Schober R. Neue Ergebnisse des II. Internationalen Lärchenprovenienzversuches von 1985/59 nach Aufnahmen von Teilversuchen in 11 europäischen Ländern und den U.S.A. Schriften aus der Forstlichen Fakultät der Universität Göttingen und der Niedersächsischen Forstlichen Versuchsanstalt 1985;83 165.

[35] Giertych M. Summary of results on European larch (Larix decidua Mill.) height growth in the IUFRO 1944 provenance experiment. Silvae Genetica 1979;28 244-256.

[36] Shutyaev AM, Giertych M. Height Growth Variation in a Comprehensive Eurasian Provenance Experiment of (Pinus sylvestris L.) Silvae Genetica 1997;46 332-349.

[37] Rehfeldt GE, Tchebakova NM, Parfenova YI, Wykoff WR, Kuzmina NA, Milyutin LI. Intraspecific responses to climate in Pinus sylvestris. Global Change Biology 2002;8 912-929.

[38] Mátyás C, Božic G, Gömöry D, Ivankovic M, Rasztovits E. Transfer analysis of provenance trials reveals macroclimatic adaptedness of European Beech (Fagus sylvatica L.) Acta Silvatica et Lignaria Hungarica 2009;5 47-62.

[39] Gömöry D, Foffová E, Kmet J, Longauer R, Romšáková I. Norway Spruce (Picea abies [L.] Karst.) Provenance Variation in Autumn Cold Hardiness: Adaptation or Acclimation? Acta Biologica Cracoviensia s. Botanica 2010;52 42-49.

[40] Kral F. Vergleichende Transpirationsstudien an Herkünften der europäischen Lärche. Centralblatt für das gesamte Forstwesen 1962;79 222-238.

[41] Petit RJ, Hampe A. Some evolutionary consequences of being a tree. Annual Review of Ecology, Evolution, and Systematics 2006;37 187-214. 
[42] Hurme P, Sillanpää M, Arjas E, Repo T, Savolainen O. Genetic basis of climatic adaptation in Scots pine by Bayesian quantitative locus analysis. Genetics 2000;156 13091322.

[43] Scotti-Saintagne C, Bodenes C, Barreneche T, Bertocchi E, Plomion C, Kremer A. Detection of quantitative trait loci controlling budburst and height growth in Quercus robur. Theoretical and Applied Genetics 2004;109 1648-1659.

[44] Kopp M, Hermisson J. The Genetic Basis of Phenotypic Adaptation I: Fixation of Beneficial Mutations in the Moving Optimum Model. Genetics 2009;182 233-249.

[45] Hermisson J, Pennings PS. Soft sweeps - molecular population genetics of adaptation from standing genetic variation. Genetics 2005;169 2335-2352.

[46] Le Corre V, Kremer A. The genetic differentiation at quantitative trait loci under local adaptation. Molecular Ecology 2012;21 1548-1566.

[47] Aitken S, Yeaman S, Holliday J, Wang T, Curtis-McLane S. Adaptation, migration or extirpation: climate change outcomes for tree populations. Evolutionary Applications 2008;1 95-111.

[48] Yeaman S, Jarvis A. Regional heterogeneity and gene flow maintain variance in a quantitative trait within populations of lodgepole pine. Proceedings Royal Society B 2006;273 1587-1593.

[49] Kremer A, Le Corre V. Decoupling of differentiation between traits and their underlying genes in response to divergent selection. Heredity 2011;108 375-85.

[50] Bird A. Perceptions of epigenetics. Nature 2007;447 396-398.

[51] Kvaalen H, Johnsen $\varnothing$. Timing of bud set in Picea abies is regulated by a memory of temperature during zygotic and somatic embryogenesis. New Phytologist 2008;177 49-59.

[52] Hewitt GM. The genetic legacy of the Quarternary ice ages. Nature 2000;405 907-913.

[53] De Carvalho D, Ingvarsson PK, Joseph J, Suter L, Sedivy C, Macaya-Sanz D, Cottrell J, Heinze B, Schanzer I, Lexer C. Admixture facilitates adaptation from standing variation in the European aspen (Populus tremula L.), a widespread forest tree. Molecular Ecology 2010;19 1638-1650.

[54] Hewitt GM. Post-glacial distribution and species substructure: lessons from pollen, insects and hybrid zones. In: Lees DR, Edwards D. (eds.) Evolutionary Patterns and Processes. London: Linnean Society Symposium Series, Academic Press; 1993. p97-123.

[55] Bialozyt R, Ziegenhagen B, Petit RJ. Contrasting effects of long distance seed dispersal on genetic diversity during range expansion. Journal of Evolutionary Biology 2006;19 12-20. 
[56] Eckert CG, Samis KE, Lougheed SC. Genetic variation across species' geographical ranges: the central-marginal hypothesis and beyond. Molecular Ecology 2008;17 $1170-1188$.

[57] Mimura M, Aitken SN. Adaptive gradients and isolation-by-distance with postglacial migration in Picea sitchensis. Heredity 2007;99 224-232.

[58] Mimura M, Aitken SN. Local adaptation at the range peripheries of Sitka spruce. Journal of Evolutionary Biology 2010;23 249-258.

[59] Crowe KA, Parker WH. Provisional breeding zone determination modelled as a maximal covering location problem. Canadian Journal Forest Research 2005;35 11731182.

[60] Hamann A, Gylander T, Chen PY. Developing seed zones and transfer guidelines with multivariate regression trees. Tree Genetics \& Genomes 2011;7 399-408.

[61] Bischoff A, Vonlanthen B, Steingera T, Müller-Schärer H. Seed provenance matters effects on germination of four plant species used for ecological restoration. Basic and Applied Ecology 2006;7 347-359.

[62] O’Brien EK, Mazanec RA, Krauss SL. Provenance variation of ecologically important traits of forest trees: implications for restoration. Journal of Applied Ecology 2007;44 583-593.

[63] Tallmon DA, Luikart G, Waples RS. The alluring simplicity and complex reality of genetic rescue. Trends in Ecology \& Evolution 2004;19 489-496.

[64] Hedrick PW. 'Genetic restoration:' a more comprehensive perspective than 'genetic rescue.' Trends in Ecology \& Evolution 2005; 20109.

[65] Bouzat JL, Johnson JA, Töpfer JE, Simpson SA, Esker TL, Westemeier RL. Beyond the beneficial effects of translocations as an effective tool for the genetic restoration of isolated populations. Conservation Genetics 2009;10 191-201.

[66] St.Clair JB, Mandel NL, Vance-Borland KW. Genecology of Douglas fir in Western Oregon and Washington. Annals of Botany 2005;96 1199-1214.

[67] St.Clair, JB, Howe GT. Genetic maladaptation of coastal Douglas-fir seedlings to future climates. Global Change Biology 2007;13 1441-1454.

[68] Matyas C. Modeling climate change effects with provenance test data. Tree physiology 1994;14 797-804.

[69] St.Clair JB. Genetic variation in fall cold hardiness in coastal Douglas-fir in western Oregon and Washington. Canadian Journal of Botany 2006;84 1110-1121.

[70] Grabner M, Karanitsch-Ackerl S, Schueler S. The influence of drought on density of Norway spruce wood. In: Kúdela, J., Lagaňa, R. (eds.) Wood Structure and Properties '10. Zvolen: Arbora Publishers; 2010. p27-33. 
[71] McLane SC, Daniels LD, Aitken SN. Climate impacts on lodgepole pine (Pinus contorta) radial growth in a provenance experiment. Forest Ecology and Management 2011;262 115-123.

[72] Krakowski J, Stoehr MU. Coastal Douglas-fir provenance variation: patterns and predictions for British Columbia seed transfer. Annals of Forest Science 2009;66 1-10.

[73] Langlet O. Two hundred years genecology. Taxon 1971;20 653-721.

[74] König AO. Provenance research: evaluating the spatial pattern of genetic variation. In: Geburek T, Turok J. (eds.): Conservation and Management of Forest Genetic Resources in Europe. Zvolen: Arbora Publishers; 2005. p275-333.

[75] Morgenstern E. Geographic variation in forest trees: genetic basis and application of knowledge in silviculture. Vancouver: UBC Press; 1996.

[76] Rehfeldt GE, Ying CC, Spittlehouse DL, Hamilton DA. Genetic responses to climate in Pinus contorta: Niche breadth, climate change, and reforestation. Ecological monographs 1999;69 375-407.

[77] Wang T, Hamann A, Yanchuk A, O'Neill GA, Aitken SN. Use of response functions in selecting lodgepole pine populations for future climates. Global Change Biology 2006;12 2404-2416.

[78] McLachlan JS, Hellmann JJ, Schwartz MW. A framework for debate of assisted migration in an era of climate change. Conservation Biology 2007;21 297-302.

[79] Ukrainetz NK, O’Neill GA, Jaquish B. Comparison of fixed and focal point seed transfer systems for reforestation and assisted migration: a case study for interior spruce in British Columbia. Canadian Journal of Forest Research 2011;41 1452-1464.

[80] Zas R. Iterative kriging for removing spatial autocorrelation in analysis of forest genetic trials. Tree Genetics \& Genomes 2006;2 177-185.

[81] Burley J, Wood PJ. A manual of species and provenance research with particular reference to the tropics. University of Oxford: CFI Tropical Forestry Paper No. 10; 1976.

[82] Cochran WG, Cox GM. Experimental designs. New York: Wiley; 1957.

[83] Hutchinson GE. Concluding Remarks. Cold Spring Harbor Symp. Quantitative Biology 1958;2 415-427.

[84] Guisan A, Thuiller W. Predicting species distribution: offering more than simple habitat models. Ecology Letters 2005;8 993-1009.

[85] O'Neill GA, Hamann A, Wang T. Accounting for population variation improves estimates of the impact of climate change on species' growth and distribution. Journal of Applied Ecology 2008;45 1040-1049. 
[86] Wang T, O'Neill GA, Aitken SN. Integrating environmental and genetic effects to predict responses of tree populations to climate. Ecological Applications 2010;20 153163.

[87] Kapeller S, Lexer MJ, Geburek T, Schüler S. Intraspecific variation in climate response of Norway spruce in the eastern Alpine range: Selecting appropriate provenances for future climate. Forest Ecology and Management 2012;271 46-57.

[88] O'Neill GA, Nigh G. Linking population genetics and tree height growth models to predict impacts of climate change on forest production. Global Change Biology 2011;17 3208-3217.

[89] Rehfeldt GE, Ferguson DE, Crookston NL. Quantifying the abundance of co-occurring conifers along inland northwest (USA) climate gradients. Ecology 2008;89 21272139 .

[90] Austin MP, Nicholls AO, Doherty MD. Determining species response functions to an environmental gradient by means of a beta-function. Journal of Vegetation 1994;5 215-228.

[91] Giertych M. Report of the IUFRO 1938 and 1939 provenance experiments on Norway spruce (Picea abies L. Karst.). Kórnik: Polish Academy of Sciences; 1984.

[92] Aitken SN, Hannerz M. Genecology and gene resource management strategies for conifer cold hardiness. In: Bigras FJ, Columbo SJ. (eds.) Conifer cold hardiness. Dordrecht: Kluwer Academic Publishers; 2001. p23-53.

[93] Mäkinen H, Nojd P, Kahle HP, Neumann U, Tveite B, Mielikainen K, Rohle H, Spiecker H. Radial growth variation of Norway spruce (Picea abies) across latitudinal and altitudinal gradients in central and northern Europe. Forest Ecology and Management 2002;171 243-259.

[94] Howe GT, Aitken SN, Neale DB, Jermstad KD, Wheeler NC, Chen THH. From genotype to phenotype: unraveling the complexities of cold adaptation in forest trees. Canadian Journal of Botany 2003;81 1247-1266.

[95] Schmidt-Vogt H. Die Fichte. Band II/1. Hamburg: Parey; 1986.

[96] Melzer H. Der Fichten-Herkunftsversuch in Loimannshagen, Ergebnisse einer Aufnahme im Jahre 1936. Centralblatt für das gesamte Forstwesen 1937;63 225-232.

[97] Günzl L. Internationale Fichten-Provenienzversuche der IUFRO 1938 und 1964/68 sowie Versuche mit österreichischen Herkünften. Allgemeine Forstzeitung 1979;90 182-190.

[98] Günzl L. Ergebnisse aus einer Fichtenprovenienzforschung. Forstliche Bundesversuchsanstalt Wien, Informationsdienst 120; 1969. 
[99] Nägeli W. Einfluss der Herkunft des Samens auf die Eigenschaften forstlicher Holzgewächse; Die Fichte. Eidgenössische Anstalt für das Forstliche Versuchswesen, Mitteilungen 1931;17 150-237.

[100] Nather J, Holzer K. Über die Bedeutung und die Anlage von Kontrollflächen zur Prüfung von anerkanntem Fichtenpflanzgut. Forstliche Bundesversuchsanstalt Wien, Informationsdienst 181; 1979.

[101] Bouvarel P. Observation sur la date de l'aoutement de quelques provenances francaises d'Epicea. Annales Nationale des Eauxet Forets de la Station de Recherche et Experience 1961;18 99-129.

[102] Liesebach M, Rau H, König AO. Fichtenherkunftsversuch von 1962 und IUFRO-Fichtenherkunftsversuch von 1972 - Ergebnisse von mehr als 30-jähriger Beobachtung in Deutschland. Beiträge aus der Nordwestdeutschen Forstlichen Versuchsanstalt 5; 2010.

[103] Krutzsch P. The IUFRO 1964/1968 Provenance Test with Norway Spruce (Picea abies (L.) Karst.). Silvae Genetica 1974;23 58-62.

[104] Korpel S, Paule L. Ergebnisse eines Provenienzversuches mit tschechoslowakischen und polnischen Herkünften der Weißtanne (Abies alba Mill.). Silvae Genetica 1984;33 (6) 177-182.

[105] Kral F. Untersuchungen zur physiologischen Charakterisierung von Tannenprovenienzen. In: Mayer H (ed.) 3. Tannen-Symposium. Vienna: Österreichischer Agrarverlag; 1980.

[106] Rütz WF, Franke A, Stimm B. Der Süddeutsche Weisstannen (Abies alba Mill.)-Provenienzversuch. Jugendentwicklung auf den Versuchsflächen. Allgemeine Forst- und Jagdzeitung 1998;169 (6/7) 116-126.

[107] Kramer W. Vorschlag für einen internationalen Herkunftsversuch von Weißtanne (Abies alba Mill.). In: Mayer H (ed.) 3. Tannen-Symposium. Vienna: Österreichischer Agrarverlag; 1980.

[108] Larsen JB. Provenienzen und Versuchsteilnehmer des IUFRO-Weißtannen-provenienzversuches von 1982. Schriften aus der Forstlichen Fakultät der Universität Göttingen und der Niedersächsischen Forstlichen Versuchsanstalt 1985;80. 239-241.

[109] Wolf H, Rütz WF, Franke A. Der süddeutsche Weißtannenprovenienzversuch: Ergebnisse der Baumschulphase und Anlage der Versuchsflächen. In: Wolf H. (ed.) Weißtannenherkünfte - Neue Resultate zur Provenienzforschung bei Abies alba Mill.: Contributiones Biologiae Arborum; 1994. p107-130.

[110] Pavari A. Esperienze e indaginisu le provenienze e razzedell'abetebianco (Abies alba Mill.). Firenze: Pubblicazioni della Regio Stazione Sperimentale di Selvicoltura 8; 1951. 
[111] Tabel U. Stand der Vorbereitungen zum 2. IUFRO-Weißtannen-Herkunftsversuch. Proceedings of the 9th International European Silver Fir Symposium, Skopje / Macedonia. IUFRO WP 1.05-16; 2000.

[112] Mayer H. Zur waldbaulich-genetischen Beurteilung der Tanne. Bericht über ein „Tannen-Symposium“ der Arbeitsgruppe Gebirgswaldbau IUFRO Sektion 23, Vienna, 1969. In: Mayer H (ed.) 3. Tannen-Symposium. Vienna: Österreichischer Agrarverlag; 1980. p169-179.

[113] Kral F. Untersuchungen zur physiologischen Charakterisierung von Tannenprovenienzen. In: Mayer H (ed.) 3. Tannen-Symposium. Vienna: Österreichischer Agrarverlag; 1980. p139-157. 